 Food Sciences
}

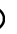

\author{
Potravinarstvo Slovak Journal of Food Sciences \\ Received: 25 June 2021. Accepted: 26 August 2021. \\ Available online: 28 September 2021 at www.potravinarstvo.com \\ (C) 2021 Potravinarstvo Slovak Journal of Food Sciences, License: CC BY 4.0
}

vol. 15, 2021, p. 846-857

https://doi.org/10.5219/1657

ISSN 1337-0960 (online)

\section{THE NUTRITIONAL VALUE, BACTERIAL COUNT AND SENSORY ATTRIBUTES OF LITTLE TUNA (EUTHYNNUS AFFINIS) FLOSS INCORPORATED WITH THE BANANA BLOSSOM}

\author{
Hartati Kartikaningsih, Yahya, Yuniar Tri Hartita, Abdul Aziz Jaziri, Wahidu Zzaman, \\ Rovina Kobun, Nurul Huda
}

\begin{abstract}
The study aimed to evaluate the addition of banana blossom $(12.5,25,37.5$, and $50 \% \mathrm{w} / \mathrm{w})$ on nutritional quality, histamine content, bacterial count, and sensory characteristic in the fish floss prepared from little tuna (Euthynnus affinis). The crude protein content, essential amino acids, lipid, and polyunsaturated fatty acids (PUFA) steadily decreased $(p<0.05)$, while the crude fibre, carbohydrate, and ash components of the tuna floss, increased significantly $(p<0.05)$ with increasing levels of banana blossom. The contents of protein, fat, ash, fibre, carbohydrate, and moisture ranged $28.13-30.27 \%, 14.79-$ $18.02 \%, 4.45-5.68 \%, 2.6-3.5 \%, 27.81-31.01$, and $16.45-17.39 \%$, respectively, and most of them met the Indonesian National Standard. For essential and non-essential amino acids, the level varied about $102.82 \mathrm{mg} . \mathrm{g}^{-1}$ to $206.76 \mathrm{mg} . \mathrm{g}^{-1}$ and $79.71 \mathrm{mg} . \mathrm{g}^{-1}$ to $138.76 \mathrm{mg} . \mathrm{g}^{-1}$, respectively in the treated tuna flosses. Moreover, ranging $13.72-16.29 \%$ of PUFA was found in all treated flosses. The most significant effect was found in the histamine levels of the tuna flosses, especially in the $50 \%$ added floss sample. Moreover, bacterial counts and heavy metals content were lower than the maximum limits regulated by the Indonesian National Standard. For sensory evaluation, the banana blossom-added samples significantly increased $(p>0.05)$ the acceptability score for all attributes assessed. Taken together, the tuna floss added with $37.5 \%$ of banana blossom may be potentially developed as a low-histamine tuna-based product with high ffibre andEPA+DHA, as well as highly acceptable for consumers.
\end{abstract}

Keywords: floss; little tuna; banana blossom; incorporation; characterizations

\section{INTRODUCTION}

Banana blossom (Musa acuminata), also commonly called banana flower, is considered as a leftover product after cultivation, which is widely consumed as a vegetable in the Southeast Asian countries, including Indonesia, Malaysia, Thailand, and the Philippines (Liyanage et al.,2016; Wahab, Ismail and Abidin, 2020). Banana blossom contains high nutritional quality, especially dietary fibre. According to Sharma, Shukla and Golani (2019), the banana blossom (100g) contained dietary fibre $(5.74 \mathrm{~g})$, protein $(1.6 \mathrm{~g})$, fat $(0.6 \mathrm{~g})$, carbohydrate $(5.7 \mathrm{~g})$, calcium (73.3mg), phosphorous $(56.4 \mathrm{mg})$ and vitamin $\mathrm{E}$ $(1.07 \mathrm{mg})$. Dietary fibre plays an essential role in lowering serum cholesterol levels, preventing obesity, normalizing blood glucose and insulin levels (Bhaskar et al., 2012; Elaveniya and Jayamuthunagai, 2014). In addition, banana blossom possesses some bioactive components, such as vitamin C, saponin, tannin, flavonoid, alphatocopherol, and myoinositol phosphates, which could promote health benefits (Somsub et al., 2008; Sheng et al., 2010). Thus, due to being rich in a range of nutrients and biologically active components, the banana blossom has gained considerable attraction as an alternative source of functional food ingredients.

Abon, also known as shredded fish or fish floss, is one of the traditional dried meat products popular among Indonesia and the Asian community. It is recognized by different local names such as serunding in Malaysia, mahu in the Philippines, moo yong in Thailand, thitheotieu in Vietnam, and rousing in China (Hang, 2015). Popular raw materials for producing floss are beef and chicken; however, some fish species are also suitable materials for shredded meat processing. The processing of floss product generally begins with steaming of washed meat until it is tender. The steamed meat is then shredded finely and mixed with some formulated spices, followed by adding coconut milk. After that, the mixture is fried and stirred continuously under heat until the mixture is dry. Finally, excessive oil in the dried meat product is then separated and removed automatically (Huda et al., 2012). Shredded 
meat is consumed as part of a daily dish or served as filler of lemper (traditional food made of glutinous rice and wrapped in a banana leaf) (Suryani, Abdurrachim and Alindah, 2016). As a dried meat product, it contains a range of nutrients, including protein/amino acids, fat/fatty acids, and ash/mineral. Protein and fat found in meat floss products are generally high at around $23.99-32.93 \%$ and $18.31-32.30 \%$, respectively (Huda et al., 2012; Wazir et al., 2019; Fahmi and Purnamayati, 2020). A high level of fat is mainly caused by cooking oil absorbed during frying. As reported by Wazir et al. (2019), the meat floss contained approximately $87.73-91.65 \%$ of saturated fatty acids. For ash value, it contains around $3.17-6.67 \%$. Among raw materials, a meat floss made of fish is much preferred by many people following the study from Huda et al. (2012), which revealed that fish floss has the highest score in overall sensory parameters compared to other meat floss samples.

Little tuna (Euthynnusaffinis) belongs to the Scombridae family that is categorized as a medium-sized tuna (Ahmed et al., 2015). It is one of the most commercially important marine fish species in Indonesia. According to the Ministry of Marine and Fisheries Affairs (2021), the total production of little tuna significantly increased around $61.27 \%$, from 366,900 tonnes in 2010 to 592,056 tonnes in 2019. In terms of nutritional value, little tuna is rich in protein and contains the amount of polyunsaturated fatty acids (PUFA). Kannaiyan et al. (2019) reported the protein content found in the white and dark muscle of little tuna was around $23.15 \%$ and $23.12 \%$, respectively, while PUFA was around $51.86 \%$ and $55.87 \%$ in the white and dark muscle, respectively. Due to nutrients rich, little tuna is extensively employed as an essential raw material for sashimi and canned products in the seafood processing industry. Also, other diversifications from little tuna have been developed, including shredded meat, nugget, dumplings, fish ball, and fish cakes (Suprayitno, Adi and Sulistiyati, 2016; Hizbullah et al., 2020). Fish floss derived from little tuna or other fish species mainly uses muscle part with adding some condiments. As a result, it has high protein content, but low dietary fibre. Moreover, histamine content would be high in the end-product because of the raw materials prepared particularly from the dark muscle of tuna and it could give rise to food-borne poisoning (Lee et al., 2016; Colombo et al., 2018). Therefore, there has been increasing interest in formulating food products with functional ingredients to deal with the unbalanced nutrition and undesirable component. Previous studies reported different quality aspects of banana blossom added nugget, noodle, biscuit, and meat floss (Wahab, Ismail and Abidin, 2020; Elaveniya and Jayamuthunagai, 2014; Komal and Kaur, 2019; Novidiyanto et al., 2020; Puspita, Kartikaningsih and Dayuti, 2019). Among them, the added banana blossom could elevate the amount of dietary fibre, antioxidant, and other functional properties.

\section{Scientific hypothesis}

There is a lack of information regarding the use of banana blossom incorporated with tuna floss in increasing fibre content and decreasing histamine levels. Therefore, this study hypothesized that incorporating little tuna floss with banana blossom may give favorable nutritional features, particularly enhancing fibre content and lowering histamine levels. Banana blossom was added up to $500 \mathrm{~g} \cdot \mathrm{kg}^{-1}$ in the formulation of little tuna floss. Nutritional aspects such as chemical composition, amino acids, fatty acids, and dietary fibre contents of the formulated little tuna floss were analyzed. Heavy metals content as safely required in the food developments was evaluated. The histamine content and pathogenic bacteria test were also determined. In addition, the sensory properties of the little tuna floss were studied to provide a basis for consumer acceptance and commercial applications. This study may stimulate further study in developing healthy fish floss products for nutritional and functional applications.

\section{MATERIAL AND METHODOLOGY}

\section{Samples}

Little tuna (E. affinis) used in this study was obtained from Sedang Biru fish market (Malang, East Java, Indonesia). The size of little tuna samples was approximately $202.8 \pm 3.3 \mathrm{~g}$ and $27.6 \pm 1.9 \mathrm{~cm}$ for weight and length, respectively. Banana blossom (M. acuminata) was purchased from a local market (Malang, East Java, Indonesia), and its weight was around $2.2 \pm 0.2 \mathrm{~kg}$.

\section{Chemicals}

All chemicals and reagents used were of analytical grade. $\mathrm{H}_{2} \mathrm{SO}_{4}$, petroleum ether and nitric acid (Merck, Germany) were supplied from a local supplier. Kjeldahl catalyst selenium tablet (Fisher Chemical, USA).

\section{Bacteria and biological material}

Bacteria used, including Escherichia coli, Salmonella sp. and Staphylococcus aureus were obtained from the Indonesian Culture Collection (InaCC), Research Center for Biology, Indonesian Institute of Sciences (LIPI). Microbial media used in a recent study were Oxoid (Basingstoke, UK)-based Nutrient agar (NA), MacConkey agar (MCA), Rappaport-Vassiliadis broth (RV), Xylose Lysine Deoxycholate (XLD) agar and Baird Parker agar (BPA).

\section{Instruments}

The instrument used consists of the oven (M720, Germany), Soxtec 2050 (FOSS Analytical, Denmark), ultra-pressure liquid chromatography (UPLC) (Waters, US), gas chromatography (GC) (Agilent Technologies, California, US), High-Performance Liquid Chromatography (HPLC) (Agilent Technologies, California, US) and Atomic Absorption Spectrophotometer (AAS) (GBC Scientific Equipment, USA).

\section{Description of the experiment}

\section{Sample preparation}

Around $15 \mathrm{~kg}$ of little tuna samples were purchased from Sendang Biru fish market (Malang, East Java, Indonesia). Fish samples were kept under cold conditions in an insulated box with ice during transportation (around 2-3 h). Upon arrival, the little tuna samples were washed in running water and were then filleted manually using a sharp knife. The filleted samples, including white and dark muscles, were stored in a freezer until use. For banana blossom, about 5 pieces of samples used were was obtained from a local market (Malang, East Java, Indonesia). Due to fresh banana blossom samples used, the 
detailed preparation was described in the following procedure for addition into little tuna floss.

Preparation of little tuna floss incorporated with banana blossom

Table 1 presents the distinct formulations for all little tuna floss samples. The banana blossoms added with banana blossom in preparing little tuna floss products were $12.5 \%$ to $50 \%$ based on the weight of the whole little tuna sample (Figure 1). The little tuna meat used consists of white and dark muscles with distinct proportions i.e., $80 \%$ and $20 \%$, respectively. These treatments were chosen in compliance with the formulated proportion for fish floss recommended by the previous study from Puspita, Kartikaningsih and Dayuti (2019). The control little tuna floss $(0 \%)$ was used as a control and compared to the treated little tuna floss samples $(12.5-50 \%)$ to evaluate the distinct characteristics of the formulation process and its corresponding attributes on the treated little tuna floss produced. During preparation, the thawed little tuna muscles were steamed at $100^{\circ} \mathrm{C}$ for $15 \mathrm{~min}$ (Halco, Indonesia). Separately, the banana flowers were cut into small sizes and then steamed at the same condition of fish treatment. After the steaming process, the steamed tuna was shredded using a fork and all ingredients used were thoroughly mixed into the pan. Afterward, the mixture samples were fried and stirred continuously under heat until the mixtures were dried. The excessive oil in the dried fish floss products was then separated and removed automatically using a spinner machine (Spiner Abon, Indonesia). All experimentations were carried out in triplicate.

\section{Nutritional attribute \\ Proximate analysis}

The proximate analysis of little tuna floss samples was determined according to the method of the Association of Official Analytical Chemists (AOAC, 2000). The Kjeldahl method was used to obtain the crude protein from all dried fish floss samples, while fat content was analyzed using the Soxhlet extractor method. The ash and moisture contents of the samples were examined by the gravimetric method. Carbohydrate content was measured by subtracting total crude protein, fat, ash, and moisture contents from $100 \%$. For energy value $\left(\mathrm{kcal} 100 \mathrm{~g}^{-1}\right)$, the calculation used the following formula provided by AACC (2000):

Energy value $=(4 \times$ carbohydrate content $)+(4 \times$ protein content $)+(9 \times$ lipid content $)$

\section{Dietary fibre analysis}

The dietary fibre analysis used in this study referred to the method of AOAC 985.29 (AOAC, 2000). The little tuna floss samples were dried at $100{ }^{\circ} \mathrm{C}$ to constant weight using air-oven (M720, Binder, Germany). Around $0.5 \mathrm{~g}$ of all samples were added $\alpha$-amylase enzyme and kept in accordance with its optimum condition (viz. $\mathrm{pH}$ 6; at $100{ }^{\circ} \mathrm{C}$, for $30 \mathrm{~min}$ ). Afterward, the treated samples were added protease with incubating at $60{ }^{\circ} \mathrm{C}$ for $30 \mathrm{~min}$ at optimum $\mathrm{pH}$ (7.5). The protease-treated samples were then added amyl-glucosidase and incubated at $\mathrm{pH} 6$ for $30 \mathrm{~min}$ at optimum temperature. Total dietary fibre of all treated samples was measured by precipitating using ethanol, followed by washing and drying. The obtained residues were then weighed manually.

\section{Amino acids analysis}

The amino acids composition was analyzed using ultrapressure liquid chromatography (UPLC) (Waters, US) according to the method of Nollet and Fidel (2015). About $5 \mathrm{~mL}$ of hydrochloric acid $6 \mathrm{~N}$ was mixed to $0.1 \mathrm{~g}$ of samples. The prepared samples were then hydrolyzed at $110{ }^{\circ} \mathrm{C}$ for $24 \mathrm{~h}$ (M720, Binder, Germany). The hydrolysed samples were transferred to prepared distilled water. After that, the mixtures were filtered with a $0.45 \mu \mathrm{m}$ filter paper. The $500 \mu \mathrm{L}$ filtrates were mixed with $40 \mu \mathrm{L}$ of 2-Amino-4-boronobutanoic acid (ABBA) and $460 \mu$ Lof double distilled water. Then, $10 \mu \mathrm{L}$ of the solution was mixed with $70 \mu \mathrm{L}$ of AccQ Fluorine Borate and $20 \mu \mathrm{L}$ of fluorine. The homogenized solutions were incubated at $55^{\circ} \mathrm{C}$ for $10 \mathrm{~min}$. Finally, the solutions were injected into the UPLC system to calculate the amino acid composition.

Fatty acids analysis

The fatty acid composition of little tuna floss was analysed by PT. Saraswanti Indo Genetech, Bogor Indonesia. Fatty acid methyl esters (FAMEs) from extracted fat of tuna floss samples were prepared by basic transesterification following the official method (AOAC, 2000), using hexane and hydroxide potassium $2 \mathrm{~N}$.

Table 1 Formulation for preparation of little tuna floss products

\begin{tabular}{|c|c|c|c|c|c|}
\hline \multirow{2}{*}{ Ingredients } & \multirow{2}{*}{$\begin{array}{l}\text { Control little tuna } \\
\text { floss }\end{array}$} & \multicolumn{4}{|c|}{ Banana blossom addition } \\
\hline & & $12.5 \%$ & $25 \%$ & $37.5 \%$ & $50 \%$ \\
\hline Little tuna meat (g) & 1000 & 870.5 & 750 & 620.5 & 500 \\
\hline Banana blossom (g) & 0 & 120.5 & 250 & 370.5 & 500 \\
\hline Coconut milk (L) & 1 & 1 & 1 & 1 & 1 \\
\hline Onion $(\mathrm{g})$ & 40 & 40 & 40 & 40 & 40 \\
\hline Garlic (g) & 10 & 10 & 10 & 10 & 10 \\
\hline Ginger (g) & 10 & 10 & 10 & 10 & 10 \\
\hline Sugar $(g)$ & 10 & 10 & 10 & 10 & 10 \\
\hline $\mathrm{NaCl}(\mathrm{g})$ & 80 & 80 & 80 & 80 & 80 \\
\hline Candlenut (g) & 5 & 5 & 5 & 5 & 5 \\
\hline Brown sugar (g) & 100 & 100 & 100 & 100 & 100 \\
\hline Lemongrass leaves (10 g) & 20 & 20 & 20 & 20 & 20 \\
\hline Lime leaves (8 pieces) & 8 & 8 & 8 & 8 & 8 \\
\hline
\end{tabular}




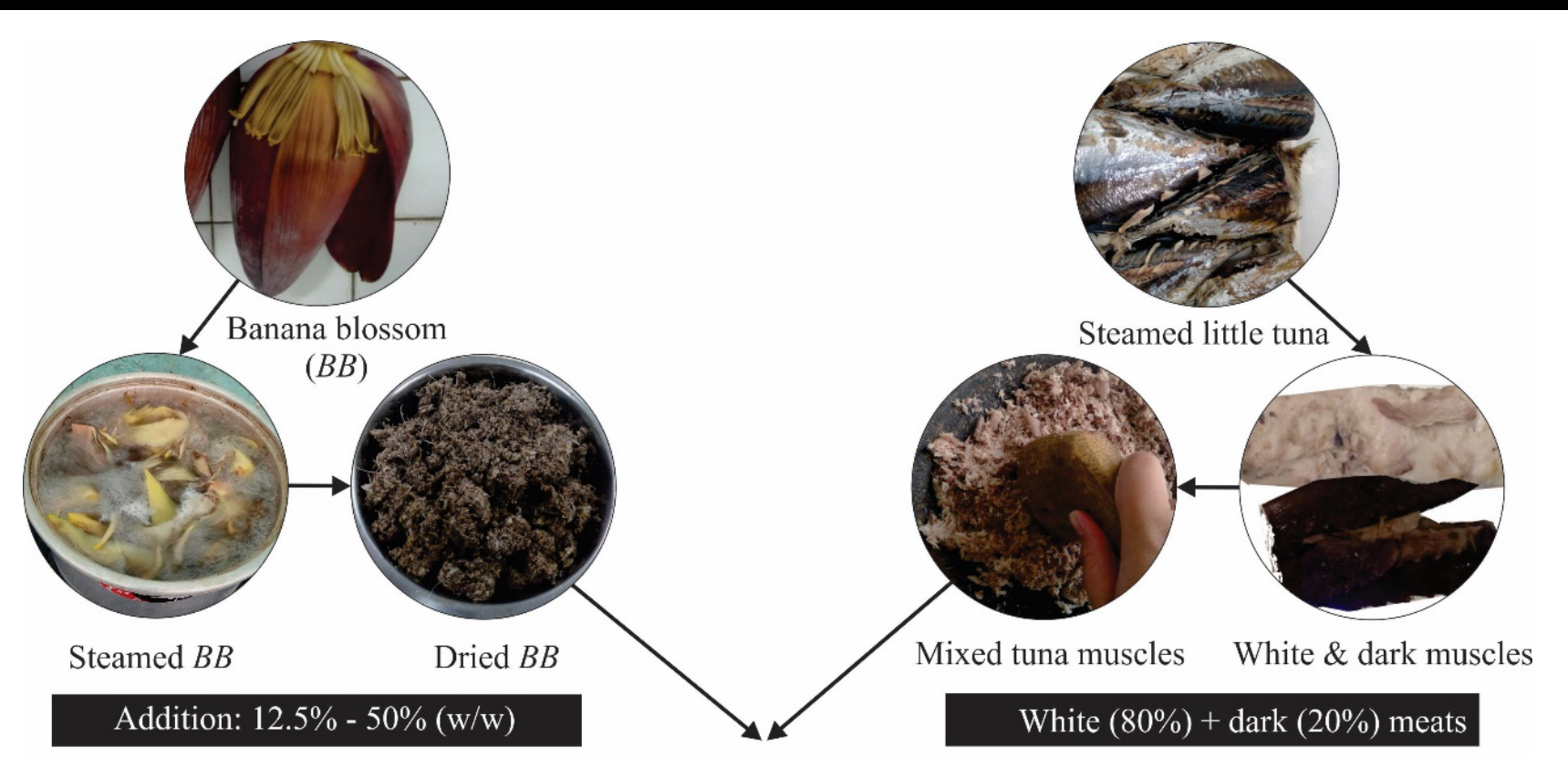

Other spices and materials were proportionally prepared, including garlic, onion, ginger, candlenut, lemongrass leaves, lime leaves, coconut milk, salt, brown sugar and refined sugar.

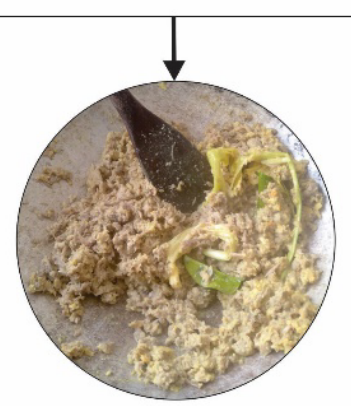

Fried and stirred mixture

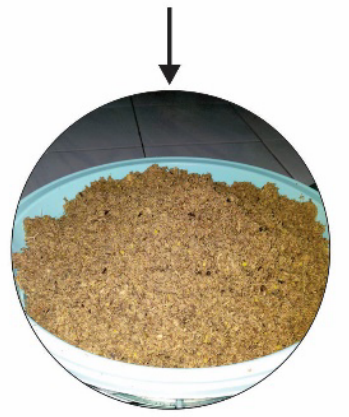

Dried abon sample

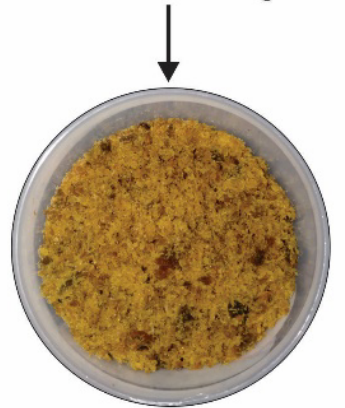

Little tuna floss after removing excessive oil using a spinner

Figure 1 Preparation of tuna floss incorporated with banana floss. 
FAMEs were analyzed by gas-chromatography (GC) (Agilent Technologies, California, US) described by Aquilani et al., (2018). The GC with a flame ionization detector (FID) was used to analyze the amount of fatty acids in the little tuna floss samples. The GC analysis was conducted using capillary column polyethylene glycol, equivalent variants CP-Wax $52 \mathrm{CB}(30 \mathrm{~m} \times 0.25 \mathrm{~mm} \times$ $0.25 \mu \mathrm{m}$ film thickness). The carrier gas was nitrogen at a flow rate of $1 \mathrm{~mL} \cdot \mathrm{min}^{-1}$. The initial oven temperature was set at $120{ }^{\circ} \mathrm{C}$ with an increase of $5{ }^{\circ} \mathrm{C}$ per minute until reached $240{ }^{\circ} \mathrm{C}$. The injector and detector temperatures were $260{ }^{\circ} \mathrm{C}$. Individual peaks were measured by comparison of their retention times (RT) with those of standards. Peak areas were calculated, and FAMEs were expressed as the area percentage of total area FAMEs (\%).

\section{Heavy metal analysis}

Heavy metals analyzed in this study were composed of cadmium $(\mathrm{Cd})$, lead $(\mathrm{Pb})$, arsenic $(\mathrm{As})$, mercury $(\mathrm{Hg})$, and tin $(\mathrm{Sn})$. These microelements were conducted by the method of AOAC (2000) using the Atomic Absorption Spectrophotometer (AAS) (GBC Scientific Equipment, USA).

\section{Histamine determination}

The histamine content was carried out by HighPerformance Liquid Chromatography (HPLC) (Agilent Technologies, California, US) according to the method from Muscarella et al., (2005). Around $10 \mathrm{~g}$ of homogenized little tuna floss was extracted by $20 \mathrm{~mL}$ of $5 \%$ trichloroacetic acid (TCA). After filtration, $1 \mathrm{~mL}$ of the extracted sample was purified with $2 \mathrm{~mL}$ of chloroform solution. The mixture was then centrifuged and $20 \mu \mathrm{L}$ of the supernatant was analyzed by HPLC. The HPLC column used was a Supelcosil LC-ABZ $4.6 \times 150 \mathrm{~mm}$, $5 \mu \mathrm{m}$ film thickness (Supelco, Bellefonte, PA, USA). The decansulphonate phosphate buffer $\mathrm{pH}$ 6.9/acetonitrile mixture (85/15) was used as a mobile phase. Isocratic elution was used; the flow rate was $1.2 \mathrm{~mL} \cdot \mathrm{min}^{-1}$. The UVDAD was regulated at the absorption wavelength of $210 \mathrm{~nm}$; the injection loop was $20 \mu \mathrm{L}$.

\section{Bacterial count}

Bacterial evaluations in the tuna floss consist of total bacteria count, total coliform, Escherichia coli, Salmonella sp., and Staphylococcus aureus with the methods developed by Anang et al. (2018) with some modifications. For total bacteria count, serial dilutions of $10-1$ to $10-5$ were prepared by diluting around $1 \mathrm{~g}$ of the little tuna floss samples into $9 \mathrm{~mL}$ of distilled water. Approximately $0.1 \mathrm{~mL}$ of aliquots from $10-3$ to $10-5$ dilutions were inoculated into Petri dishes containing the Nutrient Agar media. The plates were then incubated at $37^{\circ} \mathrm{C}$ for $24 \mathrm{~h}$. After incubation, bacteria colonies formed were counted using the colony counter and recorded as total viable counts. Total coliform was analyzed by dropping $0.1 \mathrm{~mL}$ of diluted samples into MacConkey broth with Durham tubes and incubated at $37^{\circ} \mathrm{C}$ for $24 \mathrm{~h}$. After incubation, the inoculated tubes were identified as positive total coliform by changing color from purple to yellow, and gas was collected in the Durham tubes. The positive tubes were then transferred into a $5 \mathrm{~mL}$ test tube of tryptone solution and incubated at $44{ }^{\circ} \mathrm{C}$ for $24 \mathrm{~h}$ to test $E$. coli. Afterward, a drop of Kovacs' reagent was added into the treated tubes. The suspected E. coli in each tube was shown by a red ring color development, indicating the presence of indole. Salmonella sp., the count was evaluated using pre-enrichment of bovine peptone water, followed by enrichment of Rappaport-Vassiliadis (RV) broth. After enrichment, around $0.1 \mathrm{~mL}$ of aliquots were inoculated into Xylose Lysine Deoxycholate (XLD) agar. The suspected Salmonella colonies appear colorless with a black center because of $\mathrm{H}_{2} \mathrm{~S}$ production. For S. aureus count, about $1 \mathrm{~g}$ of fish floss samples were added into test tubes containing $9 \mathrm{~mL}$ of distilled water and the mixtures were serially diluted from $10-1$ to $10-5$. Around $0.1 \mathrm{~mL}$ of aliquots $(10-3$ to $10-5)$ were inoculated into plates prepared with Baird Parker Agar media. Afterward, the inoculated samples were incubated at $36^{\circ} \mathrm{C}$ for $48 \mathrm{~h}$. After the incubation period, colonies formed were identified with the suspected colonies were round, convex with a diameter of $2-3 \mathrm{~mm}$, greyish black color with a clear circle (halo).

\section{Sensory evaluation}

Sensory parameters, including appearance, aroma, color, taste, and texture were evaluated using 30 untrained sensory panelists randomly selected among students and this method was adopted from Sęczyk, Świeca and Gawlik-Dziki (2016). The panelists were initially presented with the little tuna floss samples in identical but labeled containers with a three-digit code for their evaluation. Before the sensory session, the tuna floss samples were prepared in triplicate in a randomized permutation. This study used a hedonic test with a 9-point scale to obtain the acceptability score of the little tuna floss products. The likeness scale was arranged in accordance with the above sensory parameters was as follows: $1=$ dislike extremely; $2=$ dislike very much; $3=$ dislike moderately; $4=$ dislike slightly; $5=$ neither like nor dislike; $6=$ like slightly; $7=$ like moderately; $8=$ like very much; $9=$ like extremely.

\section{Statistical analysis}

The experimental design applied in this study was a completely randomized design (CRD). All measurements were performed in triplicate. Data were expressed as the mean values \pm standard deviation (SD). The differences were determined using a one-way analysis of variance (ANOVA), followed by Duncan's test. The significant difference was established at $p<0.05$ using SPSS, Version 27, statistical software program (SPSS Inc., Chicago, Ill., USA).

\section{RESULTS AND DISCUSSION \\ Nutritional attributes Proximate composition}

The proximate composition of little tuna floss (as a control) and floss samples incorporated with banana blossom with different levels $(12.5-50 \%)$ is presented in Table 2. Results showed a significant $(p<0.05)$ decreased in protein and fat contents of treated tuna floss samples with the increase in the percentage of banana blossom. 
Table 2 Proximate composition (g.100 $\mathrm{g}^{-1}$ ), energy value (Kcal) and histamine content (mg.kg ${ }^{-1}$ ) of the control sample and added little tuna floss with banana blossom.

\begin{tabular}{ccccccc}
\hline \multirow{2}{*}{ Parameter } & \multirow{2}{*}{$\begin{array}{c}\text { Control little } \\
\text { tuna floss }\end{array}$} & \multicolumn{1}{c}{ Banana blossom addition } & SNI* $^{*}$ \\
\cline { 3 - 7 } & & $\mathbf{1 2 . 5 \%}$ & $\mathbf{2 5 \%}$ & $\mathbf{3 7 . 5 \%}$ & $\mathbf{5 0 \%}$ & \\
\hline Moisture & $16.03 \pm 0.01^{\mathrm{a}}$ & $16.45 \pm 0.38^{\mathrm{a}}$ & $16.74 \pm 0.27^{\mathrm{a}}$ & $17.23 \pm 0.16^{\mathrm{b}}$ & $17.39 \pm 0.06^{\mathrm{b}}$ & $<7$ \\
Crude protein & $43.08 \pm 1.14^{\mathrm{d}}$ & $30.27 \pm 1.41^{\mathrm{c}}$ & $29.51 \pm 1.24^{\mathrm{b}}$ & $28.68 \pm 0.30^{\mathrm{a}}$ & $28.13 \pm 0.16^{\mathrm{a}}$ & $>15$ \\
Crude fat & $18.70 \pm 0.31^{\mathrm{c}}$ & $18.02 \pm 0.07^{\mathrm{c}}$ & $16.62 \pm 0.06^{\mathrm{b}}$ & $15.20 \pm 0.18^{\mathrm{a}}$ & $14.79 \pm 0.08^{\mathrm{a}}$ & $<30$ \\
Ash & $4.12 \pm 0.03^{\mathrm{a}}$ & $4.45 \pm 0.11^{\mathrm{a}}$ & $4.52 \pm 0.06^{\mathrm{a}}$ & $4.78 \pm 0.22^{\mathrm{a}}$ & $5.68 \pm 0.13^{\mathrm{b}}$ & $>7$ \\
Crude fibre & $1.8 \pm 0.42^{\mathrm{a}}$ & $2.6 \pm 0.21^{\mathrm{a}}$ & $2.8 \pm 0.50^{\mathrm{b}}$ & $3.1 \pm 0.43^{\mathrm{b}}$ & $3.5 \pm 0.59^{\mathrm{c}}$ & $<1$ \\
Carbohydrate & $15.07 \pm 0.58^{\mathrm{a}}$ & $27.81 \pm 1.04^{\mathrm{b}}$ & $29.61 \pm 0.43^{\mathrm{c}}$ & $31.11 \pm 0.27^{\mathrm{d}}$ & $31.01 \pm 0.20^{\mathrm{d}}$ & - \\
Energy & $271.66 \pm 1.01^{\mathrm{a}}$ & $303.69 \pm 1.84^{\mathrm{d}}$ & $297.53 \pm 0.52^{\mathrm{c}}$ & $289.92 \pm 0.25^{\mathrm{b}}$ & $285.28 \pm 0.14^{\mathrm{b}}$ & - \\
Histamine & $319.48 \pm 121^{\mathrm{e}}$ & $144.16 \pm 1.18^{\mathrm{d}}$ & $110.56 \pm 1.68^{\mathrm{c}}$ & $85.09 \pm 1.68^{\mathrm{b}}$ & $52.25 \pm 1.35^{\mathrm{a}}$ & $<200^{* *}$ \\
\hline
\end{tabular}

Note: Values are given as mean \pm standard deviation from triplicate determinations $(n=3)$. Different superscript letters in the same row indicate significant differences $(p<0.05)$. ${ }^{*}$ SNI 01-3707-1995 is used for fish floss specification. ${ }^{* *}$ Histamine limit referred to FAO/WHO (2012).

However, the protein and fat contents of all little tuna floss samples agreed with the Indonesian National Standard (SNI) values and were even much better than a limit recommended by the standard (SNI 7988, 2009) and for protein content, all treated samples were in accordance with other fish flosses (Huda et al., 2012; Wijaya et al., 2016; Romadhon, Amalia and Anggo, 2019; Fahmi and Purnamayati, 2020).

The higher protein indicates the developed tuna floss samples in this study are potentially used as a filler for low-protein food products, such as glutinous rice rolls, bread, and pastel products. The most significant effect of the formulation is the improvement in crude fibre content of the control little tuna flosses, which increased by 44.44 - $94.44 \%$ with increasing the percentage of banana blossom from $12.5-50 \%$. The increase in crude fibre content of the control tuna floss with the increase in the percentage of banana blossom was similar to the results obtained for floss incorporated with other fibre sources (Bujang et al., 2016; Candra and Tunoq, 2018; Poonsri et al., 2019) and its fibre content was higher than the values determined by SNI and other fish floss products. The higher fibre content is an indication of the better quality of the products with the potential health benefits as above mentioned. The contents of ash, carbohydrate, and moisture increased significantly $(p<0.05)$ with incorporating banana blossom in the little tuna flosses. In terms of ash content, the formulated floss samples agreed with the SNI requirements $(>7)$ for the standardized fish floss product. Moreover, the energy values of treated samples $(285.28$ - $303.69 \mathrm{kcal})$ were higher than the control $(271.66 \mathrm{kcal})$; but these values were slightly lower than the dietary requirements recommended by the FAO/WHO/UNU (2007) for children and young adult foods. The high energy level and protein content in the tuna floss added with banana blossom indicates its suitability as a supporting diet for children and young adults.

The effect of the addition of banana blossom into a tuna floss formula on histamine content is also depicted in Table 2. Interestingly, the histamine contents of treated tuna floss samples decreased significantly $(p<0.05)$ with increasing the level of banana blossom. Compared to the control sample (319.48 mg. $\left.\mathrm{kg}^{-1}\right)$, around 2-fold (144.16 mg. $\left.\mathrm{kg}^{-1}\right)$ to 6 -fold $\left(52.25 \mathrm{mg} . \mathrm{kg}^{-1}\right)$ of histamine content decreased with the increment of at around $12.5 \%$ to $50 \%$ into tuna floss samples, respectively. The reduction of histamine in the treated tuna floss might be due to the ratio of banana blossom and tuna as main materials in the development of little tuna floss products, in which a higher banana blossom was added, a lower content of histamine found in the tuna floss samples. These results were lower than found in the tuna dumpling (1608 mg. $\left.\mathrm{kg}^{-1}\right)$ studied by Chen et al. (2008), while the level of histamine in the present study showed a higher compared to the study from Peivasteh-Roudsari et al. (2020) in the canned tuna (34.46 mg. $\mathrm{kg}^{-1}$ ). Nonetheless, the histamine concentration in all treated flosses was below the $200 \mathrm{mg} . \mathrm{kg}^{-1}$ allowable limitation suggested by the FAO/WHO (2012), which would not cause an adverse effect. This histamine limit is also under the European Union Regulation (EC) No 2073/2005 (EC, 2005) for fishery products. It can be inferred that all treated tuna floss samples are safe as a food product.

\section{Amino acids composition}

Table 3. presents the profile of amino acids found in the control sample and the tuna floss incorporated with different concentrations of banana blossom. Results exhibited that glutamic acid (Glu) was the most dominant amino acid in all little tuna flosses. However, 15-amino acid analyzed in the control sample was a higher amount of total amino acids both essential and non-essential amino acids than found in the treated tuna floss products. This is due to the lower amino acids content observed in banana blossom incorporated with tuna floss samples (Table 3 ). In terms of essential amino acids, the control and treated samples showed higher values compared to the nonessential amino acids. Furthermore, the content of essential amino acids, including arginine, histidine, isoleucine. leucine, lysine, phenylalanine, threonine, and valine, found in the treated tuna floss samples did not meet the standard recommended by Food and Agriculture Organisation/World Health Organisation/United Nations 
University (FAO/WHO/UNU) for children and adult humans (FAO/WHO/UNU, 2007).

Nevertheless, fish floss is a non-staple food product like bread, noodle, and rice, which is routinely consumed in large quantities to provide adequate energy, but it is generally combined with other staple foods to enhance nutritional values.

\section{Fatty acids composition}

The effect of the formulation of tuna floss with banana blossom on the fatty acid composition is presented in Table 4. The content of fatty acids in the tuna floss samples, both control and treated samples with different levels of banana blossom, varied considerably $(p<0.05)$. The most abundant fatty acids in all treated floss samples were oleic acid (C18:1) (34.03 - 40.63\%), followed by palmitic acid (C16:0) $(27.19$ - 31.84\%) and linoleic acid (C18:2) $(11.20-13.30 \%)$, but these fatty acids were slightly lower compared to the control sample's fatty acids. It might be due to a low-fatty acids content observed in the banana blossom $(0.39-1.28 \%)$. In addition, all tuna floss incorporated with banana blossom had lower content of saturated (33.84 - 41.44\%), monounsaturated (34.37 $41.00 \%)$, and polyunsaturated $(13.72-16.29 \%)$ fatty acids than those contained in the control. However, among the identified fatty acids, omega-3 (n-3) and omega-6 (n-6) fatty acids seem to be the most important, due to their multiple biological roles, such as reducing oxidative stress, influencing the inflammatory cascade, presenting neuroprotection, and cardiovascular protection. The total $n-6$ and $n-3$ in the treated samples ranged at around 11.28 $-13.40 \%$ and $2.44-3.23 \%$ respectively, with an $n-6 / n-3$ ratio of about $3.89-4.62 \%$. These values within the range $(1-5)$ of omega-6 and omega-3 ratio per day recommended by some food experts that should be consumed to prevent undesirable diseases related to the lack of essential fatty acids intake (EFSA, 2010). Moreover, amongst $n-3$ fatty acids, eicosapentaenoic acid (EPA) and docosahexaenoic acid (DHA) are required essentially by the human body and approximately $0.2-2.0$ $\mathrm{g} /$ day recommended by most health organizations (Desai et al., 2018), and all formulated tuna floss samples met the requirements.

\section{Heavy metal content}

Heavy metals analyzed in this study are cadmium (Cd), lead $(\mathrm{Pb})$, arsenic $(\mathrm{As})$, mercury $(\mathrm{Hg})$, and tin $(\mathrm{Sn})$. These are classified as toxic metals and endanger human health if the total content of the metals exceeds the recommended exposure limits (Sajib et al., 2014; Lukáčová et al., 2014; Timoracká, Vollmannová and Ismael, 2017). As presented in Table 5, the formulation of tuna floss with different levels $(12.5-50 \%)$ of banana blossom had a wide range of metal element compositions such as $\mathrm{Cd}$ $\left(<16 \times 10-4 \mathrm{mg} \cdot \mathrm{kg}^{-1}\right), \mathrm{Pb}\left(<20 \times 10-4 \mathrm{mg} \cdot \mathrm{kg}^{-1}\right), \mathrm{As}(8 \times 10$ $\left.-4 \mathrm{mg} \cdot \mathrm{kg}^{-1}\right), \mathrm{Hg}\left(1 \times 10-4 \mathrm{mg} \cdot \mathrm{kg}^{-1}\right)$ and $\mathrm{Sn}(36.15-$ $\left.37.67 \mathrm{mg} \cdot \mathrm{kg}^{-1}\right)$.

Table 3 Amino acids composition (mg. $\mathrm{g}^{-1}$ protein) of control sample and tuna floss incorporated with banana blossom.

\begin{tabular}{|c|c|c|c|c|c|c|c|}
\hline \multirow{2}{*}{$\begin{array}{c}\text { Amino } \\
\text { acids }\end{array}$} & \multirow{2}{*}{$\begin{array}{l}\text { Banana } \\
\text { blossom }\end{array}$} & \multirow{2}{*}{$\begin{array}{l}\text { Control tuna } \\
\text { floss }\end{array}$} & \multicolumn{4}{|c|}{ Banana blossom addition } & \multirow[t]{2}{*}{ RDA* } \\
\hline & & & $12.5 \%$ & $25 \%$ & $37.5 \%$ & $50 \%$ & \\
\hline Ala & $0.88 \pm 0.00$ & $12.60 \pm 0.04^{\mathrm{e}}$ & $10.43 \pm 0.03^{\mathrm{d}}$ & $6.92 \pm 0.03^{\mathrm{c}}$ & $6.43 \pm 0.01^{\mathrm{b}}$ & $6.27 \pm 0.02^{\mathrm{a}}$ & - \\
\hline Arg & $1.36 \pm 0.01$ & $32.81 \pm 0.05^{\mathrm{e}}$ & $26.73 \pm 0.07^{\mathrm{d}}$ & $16.05 \pm 0.04^{c}$ & $14.68 \pm 0.29^{b}$ & $11.13 \pm 0.03^{\mathrm{a}}$ & 20 \\
\hline Asp & $1.58 \pm 0.00$ & $34.90 \pm 0.13^{\mathrm{e}}$ & $28.94 \pm 0.07^{\mathrm{d}}$ & $20.54 \pm 0.10^{c}$ & $19.65 \pm 0.16^{b}$ & $17.71 \pm 0.01^{\mathrm{a}}$ & - \\
\hline Glu & $2.08 \pm 0.02$ & $55.88 \pm 0.17^{\mathrm{e}}$ & $46.82 \pm 0.12^{\mathrm{d}}$ & $32.25 \pm 0.08^{c}$ & $30.86 \pm 0.05^{b}$ & $28.80 \pm 0.06^{\mathrm{a}}$ & - \\
\hline Gly & $1.05 \pm 0.01$ & $24.43 \pm 0.05^{\mathrm{e}}$ & $20.34 \pm 0.03^{\mathrm{d}}$ & $12.76 \pm 0.01^{\mathrm{c}}$ & $11.82 \pm 0.23^{b}$ & $10.17 \pm 0.02^{\mathrm{a}}$ & - \\
\hline His & $0.62 \pm 0.01$ & $25.31 \pm 0.10^{\mathrm{e}}$ & $19.71 \pm 0.09^{d}$ & $13.22 \pm 0.06^{\mathrm{c}}$ & $10.43 \pm 0.14^{b}$ & $8.55 \pm 0.02^{\mathrm{a}}$ & $15-16$ \\
\hline Ile & $0.94 \pm 0.01$ & $24.29 \pm 0.08^{\mathrm{e}}$ & $19.81 \pm 0.05^{\mathrm{d}}$ & $11.93 \pm 0.04^{\mathrm{c}}$ & $11.55 \pm 0.11^{\mathrm{b}}$ & $10.46 \pm 0.02^{\mathrm{a}}$ & $30-31$ \\
\hline Leu & $1.11 \pm 0.01$ & $40.84 \pm 0.15^{\mathrm{e}}$ & $33.57 \pm 0.08^{\mathrm{d}}$ & $20.25 \pm 0.08^{c}$ & $19.23 \pm 0.03^{b}$ & $18.08 \pm 0.02^{\mathrm{a}}$ & $59-61$ \\
\hline Lys & $0.78 \pm 0.01$ & $32.12 \pm 0.10^{\mathrm{e}}$ & $26.41 \pm 0.08^{\mathrm{d}}$ & $18.57 \pm 0.06^{\mathrm{c}}$ & $17.96 \pm 0.01^{\mathrm{b}}$ & $17.26 \pm 0.03^{\mathrm{a}}$ & $45-48$ \\
\hline Phe & $0.76 \pm 0.01$ & $26.69 \pm 0.15^{\mathrm{e}}$ & $21.02 \pm 0.03^{\mathrm{d}}$ & $13.63 \pm 0.00^{c}$ & $11.09 \pm 0.57^{b}$ & $8.63 \pm 0.03^{a}$ & 38 \\
\hline Pro & $0.90 \pm 0.01$ & $15.14 \pm 0.05^{\mathrm{d}}$ & $12.76 \pm 0.04^{\mathrm{c}}$ & $8.11 \pm 0.03^{b}$ & $7.40 \pm 0.02^{\mathrm{a}}$ & $7.38 \pm 0.02^{\mathrm{a}}$ & - \\
\hline Ser & $1.40 \pm 0.01$ & $24.42 \pm 0.08^{\mathrm{e}}$ & $19.47 \pm 0.06^{\mathrm{d}}$ & $11.53 \pm 0.03^{\mathrm{c}}$ & $10.62 \pm 0.08^{\mathrm{b}}$ & $9.37 \pm 0.02^{\mathrm{a}}$ & - \\
\hline Thr & $0.86 \pm 0.01$ & $28.99 \pm 0.09^{\mathrm{e}}$ & $23.60 \pm 0.09^{d}$ & $14.09 \pm 0.06^{\mathrm{c}}$ & $13.63 \pm 0.06^{b}$ & $10.80 \pm 0.03^{\mathrm{a}}$ & $23-25$ \\
\hline Tyr & $0.67 \pm 0.00$ & $16.27 \pm 0.07^{\mathrm{e}}$ & $13.67 \pm 0.03^{\mathrm{d}}$ & $8.25 \pm 0.04^{c}$ & $6.46 \pm 0.03^{b}$ & $5.24 \pm 0.03^{\mathrm{a}}$ & - \\
\hline Val & $0.94 \pm 0.01$ & $27.32 \pm 0.09^{\mathrm{d}}$ & $22.24 \pm 0.09^{c}$ & $13.98 \pm 0.02^{b}$ & $12.84 \pm 0.06^{\mathrm{a}}$ & $12.67 \pm 0.01^{\mathrm{a}}$ & $39-40$ \\
\hline $\begin{array}{c}\text { TEAA* } \\
*\end{array}$ & 8.05 & $254.56^{\mathrm{e}}$ & $206.76^{\mathrm{d}}$ & $129.97^{\mathrm{c}}$ & $118.35^{\mathrm{b}}$ & $102.82^{\mathrm{a}}$ & - \\
\hline$\underset{* * *}{\text { TNEAA }}$ & 7.89 & $167.37^{\mathrm{e}}$ & $138.76^{\mathrm{d}}$ & $92.12^{\mathrm{c}}$ & $86.27^{b}$ & $79.71^{\mathrm{a}}$ & - \\
\hline
\end{tabular}

Note: Values are given as mean \pm standard deviation from triplicate determinations $(n=3)$. Different letters in the same row indicate significant differences $(p<0.05) . *$ RDA: Recommended dietary allowance for children and adult humans by FAO/WHO/UNU (2007). ** TEAA: total essential amino acids (arginine, histidine, isoleucine. leucine, lysine, phenylalanine, threonine and valine). ${ }^{* * *}$ TNEAA: total non-essential amino acids (aspartic acid, glutamic acid, serine, tyrosine, glycine and alanine). 
Table 4 Fatty acids profile (\%) of control tuna floss and treated tuna floss with addition of banana blossom.

\begin{tabular}{|c|c|c|c|c|c|c|}
\hline \multirow{2}{*}{ Fatty acids } & \multirow{2}{*}{$\begin{array}{l}\text { Banana } \\
\text { blossom }\end{array}$} & \multirow{2}{*}{$\begin{array}{l}\text { Control tuna } \\
\text { floss }\end{array}$} & \multicolumn{4}{|c|}{ Banana blossom addition } \\
\hline & & & $12.5 \%$ & $25 \%$ & $37.5 \%$ & $50 \%$ \\
\hline C6:0 & n.d. & $0.04 \pm 0.000^{b}$ & $0.03 \pm 0.001^{\mathrm{a}}$ & $0.04 \pm 0.000^{b}$ & n.d. & n.d. \\
\hline $\mathrm{C} 8: 0$ & n.d. & $0.38 \pm 0.007^{\mathrm{c}}$ & $0.37 \pm 0.006^{\mathrm{c}}$ & $0.44 \pm 0.009^{\mathrm{d}}$ & $0.23 \pm 0.001^{\mathrm{b}}$ & $0.17 \pm 0.000^{\mathrm{a}}$ \\
\hline $\mathrm{C} 10: 0$ & n.d. & $0.25 \pm 0.002^{\mathrm{c}}$ & $0.26 \pm 0.003^{\mathrm{c}}$ & $0.33 \pm 0.006^{\mathrm{d}}$ & $0.16 \pm 0.002^{\mathrm{b}}$ & $0.13 \pm 0.001^{\mathrm{a}}$ \\
\hline $\mathrm{C} 12: 0$ & n.d. & $2.15 \pm 0.051^{\mathrm{c}}$ & n.d. & $2.68 \pm 0.063^{d}$ & $1.35 \pm 0.005^{\mathrm{b}}$ & $1.14 \pm 0.000^{\mathrm{a}}$ \\
\hline $\mathrm{C} 14: 0$ & $0.02 \pm 0.000$ & $1.71 \pm 0.014^{\mathrm{a}}$ & $1.76 \pm 0.041^{\mathrm{a}}$ & $1.85 \pm 0.012^{b}$ & $1.20 \pm 0.012^{\mathrm{b}}$ & $1.25 \pm 0.001^{\mathrm{c}}$ \\
\hline $\mathrm{C} 15: 0$ & n.d. & $0.05 \pm 0.000^{\mathrm{b}}$ & $0.04 \pm 0.000^{\mathrm{a}}$ & $0.04 \pm 0.000^{\mathrm{a}}$ & $0.04 \pm 0.001^{\mathrm{a}}$ & $0.03 \pm 0.000^{\mathrm{a}}$ \\
\hline $\mathrm{C} 16: 0$ & $0.92 \pm 0.010$ & $32.52 \pm 0.056^{c}$ & $31.84 \pm 0.433^{\mathrm{c}}$ & $28.83 \pm 0.115^{\mathrm{b}}$ & $27.47 \pm 0.224^{\mathrm{a}}$ & $27.19 \pm 0.016^{\mathrm{a}}$ \\
\hline C16:1 & $0.02 \pm 0.000$ & $0.19 \pm 0.000$ & $0.17 \pm 0.004$ & $0.16 \pm 0.001$ & $0.16 \pm 0.001$ & $0.15 \pm 0.001$ \\
\hline $\mathrm{C} 17: 0$ & n.d. & $0.12 \pm 0.000$ & $0.10 \pm 0.001$ & $0.10 \pm 0.000$ & $0.10 \pm 0.001$ & $0.09 \pm 0.000$ \\
\hline $\mathrm{C} 17: 1$ & n.d. & $0.04 \pm 0.001$ & $0.03 \pm 0.000$ & $0.03 \pm 0.001$ & $0.02 \pm 0.000$ & $0.03 \pm 0.000$ \\
\hline C18:0 & $0.12 \pm 0.000$ & $4.53 \pm 0.004^{\mathrm{e}}$ & $4.31 \pm 0.061^{\mathrm{d}}$ & $3.93 \pm 0.004^{\mathrm{c}}$ & $3.68 \pm 0.024^{b}$ & $3.47 \pm 0.002^{\mathrm{a}}$ \\
\hline C18:1n9 & $0.39 \pm 0.001$ & $41.99 \pm 0.020^{\mathrm{e}}$ & $40.63 \pm 0.323^{\mathrm{d}}$ & $35.86 \pm 0.001^{\mathrm{c}}$ & $34.97 \pm 0.139^{b}$ & $34.03 \pm 0.012^{\mathrm{a}}$ \\
\hline $\mathrm{C} 18: 2 \mathrm{n} 6$ & $1.28 \pm 0.000$ & $14.02 \pm 0.008^{\mathrm{d}}$ & $13.30 \pm 0.106^{\mathrm{c}}$ & $12.42 \pm 0.001^{\mathrm{b}}$ & $11.25 \pm 0.042^{\mathrm{a}}$ & $11.20 \pm 0.000^{\mathrm{a}}$ \\
\hline $\mathrm{C} 18: 3 \mathrm{n} 3$ & $0.36 \pm 0.000$ & $2.45 \pm 0.000^{\mathrm{e}}$ & $2.17 \pm 0.023^{\mathrm{c}}$ & $2.28 \pm 0.002^{\mathrm{d}}$ & $1.68 \pm 0.008^{\mathrm{a}}$ & $1.79 \pm 0.000^{\mathrm{b}}$ \\
\hline C20:0 & $0.24 \pm 0.003$ & $0.38 \pm 0.006^{\mathrm{d}}$ & $0.35 \pm 0.007^{\mathrm{c}}$ & $0.30 \pm 0.002^{b}$ & $0.29 \pm 0.007^{b}$ & $0.27 \pm 0.001^{\mathrm{a}}$ \\
\hline C20:1 & $0.14 \pm 0.000$ & n.d. & $0.17 \pm 0.004$ & $0.16 \pm 0.000$ & $0.16 \pm 0.002$ & n.d. \\
\hline $\mathrm{C} 20: 4 \mathrm{n} 6$ & n.d. & $0.11 \pm 0.001^{\mathrm{c}}$ & $0.10 \pm 0.002^{b}$ & $0.12 \pm 0.002^{\mathrm{d}}$ & $0.12 \pm 0.003^{d}$ & $0.08 \pm 0.001^{\mathrm{a}}$ \\
\hline $\mathrm{C} 20: 5 \mathrm{n} 3$ & n.d. & $0.20 \pm 0.003^{c}$ & $0.18 \pm 0.004^{\mathrm{a}}$ & $0.19 \pm 0.002^{b}$ & $0.21 \pm 0.003^{c}$ & $0.17 \pm 0.000^{\mathrm{a}}$ \\
\hline $\mathrm{C} 21: 1$ & n.d. & $0.18 \pm 0.001$ & n.d. & n.d. & n.d. & n.d. \\
\hline $\mathrm{C} 22: 6 \mathrm{n} 3$ & n.d. & $0.64 \pm 0.012^{\mathrm{c}}$ & $0.55 \pm 0.008^{b}$ & $0.76 \pm 0.006^{\mathrm{d}}$ & $0.67 \pm 0.016^{c}$ & $0.48 \pm 0.000^{\mathrm{a}}$ \\
\hline $\mathrm{C} 24: 0$ & $0.02 \pm 0.000$ & $0.13 \pm 0.002$ & $0.10 \pm 0.001$ & $0.10 \pm 0.002$ & $0.12 \pm 0.000$ & $0.10 \pm 0.001$ \\
\hline$\sum \mathrm{SFA}$ & $1.38 \pm 0.005$ & $42.25 \pm 0.031^{\mathrm{e}}$ & $41.44 \pm 0.443^{\mathrm{d}}$ & $38.63 \pm 0.030^{c}$ & $34.65 \pm 0.197^{b}$ & $33.84 \pm 0.027^{\mathrm{a}}$ \\
\hline$\sum$ MUFA & $0.62 \pm 0.001$ & $42.40 \pm 0.019^{\mathrm{e}}$ & $41.00 \pm 0.323^{\mathrm{d}}$ & $36.21 \pm 0.001^{\mathrm{c}}$ & $35.31 \pm 0.139^{b}$ & $34.37 \pm 0.012^{\mathrm{a}}$ \\
\hline$\sum$ PUFA & $1.64 \pm 0.000$ & $17.42 \pm 0.009^{\mathrm{d}}$ & $16.29 \pm 0.143^{c}$ & $15.77 \pm 0.008^{b}$ & $13.93 \pm 0.073^{\mathrm{a}}$ & $13.72 \pm 0.001^{\mathrm{a}}$ \\
\hline$\sum \mathrm{n} 6$ & $1.28 \pm 0.000$ & $14.13 \pm 0.004^{\mathrm{d}}$ & $13.40 \pm 0.004^{c}$ & $12.54 \pm 0.001^{\mathrm{b}}$ & $11.37 \pm 0.004^{\mathrm{a}}$ & $11.28 \pm 0.001^{\mathrm{a}}$ \\
\hline$\sum \mathrm{n} 3$ & $0.36 \pm 0.000$ & $3.29 \pm 0.007^{\mathrm{e}}$ & $2.90 \pm 0.011^{\mathrm{c}}$ & $3.23 \pm 0.005^{\mathrm{d}}$ & $2.56 \pm 0.009^{\mathrm{b}}$ & $2.44 \pm 0.000^{\mathrm{a}}$ \\
\hline PUFA/SFA & $6.54 \pm 0.025$ & $2.27 \pm 0.001^{\mathrm{b}}$ & $2.16 \pm 0.042^{\mathrm{a}}$ & $2.25 \pm 0.003^{b}$ & $2.21 \pm 0.024^{\mathrm{ab}}$ & $2.23 \pm 0.002^{\mathrm{ab}}$ \\
\hline $\mathrm{EPA}+\mathrm{DHA}$ & n.d. & $0.84 \pm 0.015^{\mathrm{c}}$ & $0.73 \pm 0.012^{b}$ & $0.95 \pm 0.009^{d}$ & $0.88 \pm 0.019^{c}$ & $0.65 \pm 0.000^{\mathrm{a}}$ \\
\hline $\mathrm{n} 6 / \mathrm{n} 3$ & 3.56 & 4.29 & 4.62 & 3.89 & 4.44 & 4.62 \\
\hline
\end{tabular}

Note: Values are given as mean \pm standard deviation from triplicate determinations $(n=3)$. Different superscript letters in the same row indicate significant differences $(p<0.05)$.

Table 5 Heavy metals content (mg. $\mathrm{kg}^{-1}$ ) of control and added tuna floss samples with banana blossom.

\begin{tabular}{|c|c|c|c|c|c|c|}
\hline \multirow{2}{*}{ Elements } & \multirow{2}{*}{$\begin{array}{l}\text { Control little } \\
\text { tuna floss }\end{array}$} & \multicolumn{4}{|c|}{ Banana blossom addition } & \multirow[t]{2}{*}{ SNI* } \\
\hline & & $12.5 \%$ & $25 \%$ & $37.5 \%$ & $50 \%$ & \\
\hline $\mathrm{Cd}$ & $<0.0016$ & $<0.0016$ & $<0.0016$ & $<0.0016$ & $<0.0016$ & $<0.50$ \\
\hline $\mathrm{Pb}$ & $<0.0020$ & $<0.0020$ & $<0.0020$ & $<0.0020$ & $<0.0020$ & $<2.00$ \\
\hline As & $<0.0008$ & $<0.0008$ & $<0.0008$ & $<0.0008$ & $<0.0008$ & $<1.00$ \\
\hline $\mathrm{Hg}$ & $<0.0001$ & $<0.0001$ & $<0.0001$ & $<0.0001$ & $<0.0001$ & $<0.05$ \\
\hline $\mathrm{Sn}$ & $27.53 \pm 0.41^{\mathrm{a}}$ & $36.15 \pm 0.120^{\mathrm{b}}$ & $34.21 \pm 0.10^{\mathrm{b}}$ & $37.67 \pm 0.20^{\mathrm{b}}$ & $37.3 \pm 0.20^{\mathrm{b}}$ & $<40.00$ \\
\hline
\end{tabular}

Note: Values are given as mean \pm standard deviation from triplicate determinations $(n=3)$. Different superscript letters in the same row indicate significant differences $(p<0.05)$. ${ }^{*}$ SNI $01-3707-1995$ is used for fish floss specification. 
Compared to the control treatment, all identified elements were relatively the same in the contents except amount of $\mathrm{Sn}$, which the content of $\mathrm{Sn}$ increased significantly $(p<0.05)$. However, all heavy metals contained in the treated samples agreed with the Indonesian National Standard for fish floss specification (SNI 01-3707, 1995). It indicates that the tuna floss incorporated with a banana blossom is potentially safe for human beings.

\section{Bacterial test}

Table 6. shows the bacterial counts for all tuna floss samples evaluated with different tests, including total count, Salmonella sp., E. coli, S. aureus, and total coliform. For total bacterial count, a non-selective media was used, and the results presented that no significant difference $(p>0.05)$ was exhibited in the total bacterial count and slightly higher compared to scad fish (Decapterus sp.) floss (Kasmiati et al., 2020). However, all treated samples did not exceed the maximum permissible limits of microbial contamination in food products regulated by the Indonesian National Standard (SNI 7988, 2009). The identification of Salmonella sp., E. coli, $S$. aureus in the tuna floss samples using specific media showed no growth (negative) after incubation and these results agreed with the requirement for microbial contamination in the dried fish product (SNI 7988, 2009). Furthermore, all treated samples, both augmented and unaugmented with banana blossom, showed a similar count

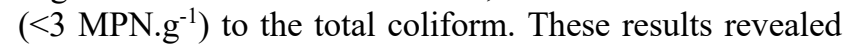
that the total coliform in all tested samples were within the acceptable microbial quality of the Indonesia National Standard. From those microbial evaluations, the tuna floss product used in the present study agrees with the SNI 7988: 2009.

\section{Sensory attribute}

Sensory evaluation is a suitable tool for developing food products with assessing consumer's acceptance (Anang et al., 2018; Fiorentini, Kinchla and Nolden, 2020; Witczak, Jaworska and Witczak, 2020).

Table 6 Bacterial count of control tuna floss and tuna flosses added with banana blossom.

\begin{tabular}{|c|c|c|c|c|c|c|}
\hline \multirow{2}{*}{ Bacterial test } & \multirow{2}{*}{$\begin{array}{c}\text { Control tuna } \\
\text { floss }\end{array}$} & \multicolumn{4}{|c|}{ Banana blossom addition } & \multirow[t]{2}{*}{ SNI* } \\
\hline & & $12.5 \%$ & $25 \%$ & $37.5 \%$ & $50 \%$ & \\
\hline Total count $\left(\mathrm{cfu} . \mathrm{g}^{-\mathbf{1}}\right)$ & $3.4 \times 10^{4}$ & $1.6 \times 10^{4}$ & $3.3 \times 10^{4}$ & $5.2 \times 10^{4}$ & $1.1 \times 10^{4}$ & $<1 \times 10^{5}$ \\
\hline Salmonella sp. (cfu.g $\left.{ }^{-1}\right)$ & negative & negative & negative & negative & negative & negative \\
\hline E. coli $\left(\right.$ cfu.g $\left.{ }^{-1}\right)$ & negative & negative & negative & negative & negative & $<3$ \\
\hline S. aureus (cfu.g ${ }^{-1}$ ) & negative & negative & negative & negative & negative & $<1 \times 10^{2}$ \\
\hline Total coliform (MPN.g $\left.\mathrm{g}^{-\mathbf{1}}\right)$ & $<3$ & $<3$ & $<3$ & $<3$ & $<3$ & $<10$ \\
\hline
\end{tabular}

Note: *SNI 7988: 2009: maximum permissible limits of microbial contamination in food products.

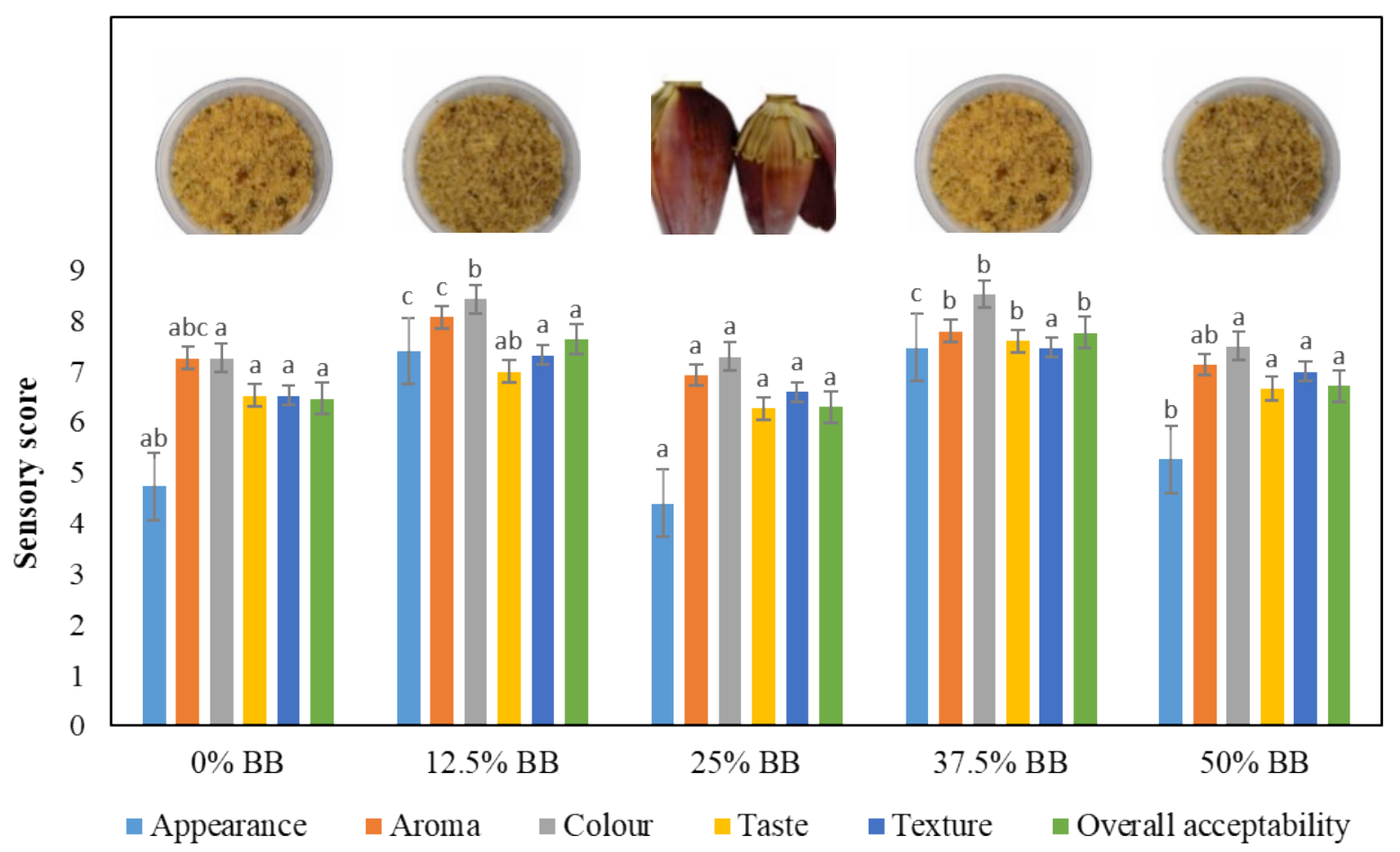

Figure 2 Physical appearance and sensory attributes of control tuna floss and tuna floss incorporated with different levels $(12.5-50 \%)$ of banana blossom. The same letters denote the lack of statistically significant differences between the results at $p<0.05(n=30)$. 
Assessment of sensory attributes (appearance, aroma, color, taste, texture, and overall quality) of tested tuna floss by the panelist is depicted in Figure 2. Generally, the addition of banana blossom at the level from $12.5 \%$ to $50 \%$ to tuna flosses had a significant influence $(p<0.05)$ on its sensory characteristics and consequently on consumer acceptance. Amongst these formulations, the $37.5 \%$ added floss showed the highest scores in almost assessed attributes compared to other treatments and control samples.

In addition, the mean score of overall acceptability in the tested floss samples was approximately 7.11, which implies that the treatment of tuna flosses is preferred moderately among the consumers. This acceptability value agreed with the requirement recommended by the Indonesian National Standard (5) (SNI 01-3707, 1995), and even much higher than the score accepted by the SNI. Also, these results are in accordance with the studies from Candra and Tunoq (2018), Puspita, Kartikaningsih and Dayuti (2019) and Novidiyanto et al., (2020) used the addition of banana flowers into snakehead (Channa striata), Indian scad (Decapterusrusselli) and chicken floss products, respectively.

\section{CONCLUSION}

Taken together, the addition of tuna floss with different levels $(12.5 \%-50 \%)$ of banana blossom reduced histamine level and increased the dietary fibre content in the little tuna floss samples. In addition, microbial and toxic elements were permissible limits regulated by the Indonesian National Standard (SNI) in all the treated tuna flosses. Our results suggested that $37.5 \%$ of banana blossom incorporated into the tuna flosses was selected as an appropriate formula due to its attributes, such as being more acceptable for overall sensory evaluation, high contents of EPA+DHA, and dietary fibre, as well as a low histamine content. However, our further research concerns the nutritional value of the selected tuna floss sample, especially on the enrichment of essential amino acids composition through fortification strategy. Also, functional properties like antioxidant and antimicrobial activities will be further studied.

\section{REFERENCES}

AACC. 2000. Approved methods of the American Association of Cereal Chemists, $10^{\text {th }}$ ed. St. Paul, MN, USA.

Ahmed, Q., Yousuf, F., Sarfraz, M.,Ali, Q. M.,Balkhour, M., Safi, S. Z., Ashraf, M. A. 2015. Euthynnus affinis (little tuna): fishery, bionomics, seasonal elemental variations, health risk assessment and conservational management. Frontiers in Life Science, vol. 8, no. 1, p. 71-96, https://doi.org/10.1080/21553769.2014.961617.

Anang, D. A., Probee, R. A., Antwi, E., Obeng, E. M., Atter, A., Ayittey, F. K., Boateng, J. T. 2018. Nutritional, microbial and sensory attributes of bread fortified with defatted watermelon seed flour. International Journal of Food Science \& Technology, vol. 53, no. 6, p. 1468-1475. https://doi.org/10.1111/ijfs.13727

AOAC. 2000. Official methods of analysis, $17^{\text {th }} \mathrm{ed}$. Washington.Association of Official Analytical Chemist.

Aquilani, C., Pérez-Palacios, T., Sirtori, F., Jiménez-Martín, E., Antequera, T., Franci, O., Acciaioli, A., Bozzi, R., Pugliese, C. 2018. Enrichment of cinta senese burgers with omega-3 fatty acids. effect of type of addition and storage conditions on quality characteristics. Grasas Aceites, vol. 69, no. 1, p. e235. https://doi.org/10.3989/gya.0671171

Bhaskar, J. J., Mahadevamma, S., Chilkunda, N. D., Salimath, P. V. 2012. Banana (Musa sp. var. elakki bale) flower and pseudostem: dietary fiber and associated antioxidant capacity. Journal of Agricultural and Food Chemistry, vol. 60, p. 427-432. https://doi.org/10.1021/jf204539v

Bujang, A., Jamil, S. S., Basar, N. F., Nor, N. M. 2016. Nutrient content, sensory and storage stability of meat floss incorporated with cassava leaves. IOSR Journal of Environmental Science, Toxicology and Food Technology, vol. 10, no. 9, p. 30-34. https://doi.org/10.9790/24021009013034

Candra, K. P., Tunoq, A. 2018. Chemical properties and sensory acceptance of shredded snakehead fish (Channa striata) meat formulated by male flowers of kepok banana (Musa acuminata balbisiana Linn) (Sifat kimia dan penerimaan sensori dari abon dengan formulasi daging ikan gabus (Channa striata) dan jantung pisang kepok (Musa acuminata balbisiana Linn). Jurnal Teknologi Pertanian Universitas Mulawarman, vol. 13, no. 2, p. 45-50. (in Indonesian)

Chen, H. C., Kung, H. F., Chen, W. C., Lin, W. F., Hwang, D. F., Lee, Y. C., Tsai, Y. H. 2008. Determination of histamine and histamine-forming bacteria in tuna dumpling implicated in a food-borne poisoning, Food Chemistry, vol. 106 ,

$$
\text { p. }
$$

$612-618$

https://doi.org/10.1016/j.foodchem.2007.06.020

Colombo, F. M.,Cattaneo, P., Confalonieri, E.,Bernardi, C. 2018. Histamine food poisonings: A systematic review and meta-analysis. Critical Reviews in Food Science and Nutrition, vol. 3, no. 58, p. 1131-1151. https://doi.org/10.1080/10408398.2016.1242476

Desai, A. S., Beibeia, T., Brennan, M. A., Guo, X., Zeng, A. A., Brennan, C. S. 2018. Protein, amino acid, fatty acid composition, and in vitro digestibility of bread fortified with Oncorhynchus tschawytscha powder. Nutrients, vol. 10, p. 1923. https://doi.org/10.3390/nu10121923

EC. 2005. European Commission Regulation No 2073/2005 on microbiological criteria for foodstuffs. Official Journal of the European Union.

EFSA. 2010. S. Outcome of the Public consultation on the Draft Opinion of the Scientific Panel on Dietetic Products, Nutrition, and Allergies (NDA) on Dietary Reference Values for fats, including saturated fatty acids, polyunsaturated fatty acids, monounsaturated fatty acids, trans fatty acids, and cholesterol. Eur. Food Safety Authority.

Elaveniya, E., Jayamuthunagai, J. 2014. Functional, physicochemical and antioxidant properties of dehydrated banana blossom powder and its incorporation in biscuits. International Journal of ChemTech Research, vol. 6, no. 9, p. 4446-4454.

Fahmi, A. S., Purnamayati, L. 2020. Cholesterol content, fatty acid composition and sensory analysis of deep fried and roasted abon ikan (fish floss/shredded fish flesh). In the 3rd International Symposium on Marine and Fisheries Research (3rd ISMFR): Proceedings. Vol 147. Innovative Research in Marine and Fisheries towards Seafood and Nutrition Sustainability. Yogyakarta, Indonesia: Publisher EDP Science. ISBN 9781713806868. https://doi.org/10.1051/ e3sconf $/ 202014703009$

FAO/WHO. 2012. Joint FAO/WHO Expert Meeting on the Public Health Risks of Histamine and Other Biogenic Amines from Fish and Fishery Products. Joint FAO/WHO expert meeting report. Rome: FAO Headquarters. 
FAO/WHO/UNU. 2007. Protein and Amino Acid Requirements in Human Nutrition: Report of a Joint FAO/WHO/UNU Expert Consultation; WHO Technical Reports Series No. 935; FAO/WHO/UNU: Geneva, Switzerland.

Fiorentini, M., Kinchla, A. J., Nolden, A. A. 2020. Role of sensory evaluation in consumer acceptance of plant-based meat analogs and meat extenders: a scoping review. Foods, vol. 9, no. 9, p. 1334. https://doi.org/10.3390/foods9091334

Hang, N. T. 2015. Process development for production of smoked fish floss products from Atlantic mackerel and Blue whiting. Iceland : United Nations University Fisheries Training Programme.

Hizbullah, H. H., Sari, N. K., Nurhayati, T., Nurimala, M. 2020. Quality changes of little tuna fillet (Euthynnusaffinis) during chilling temperature storage. In the 4th EMBRIO International Symposium and the 7th International Symposium of East Asia Fisheries and Technologists Association: Proceedings. Vol 404. Bogor, Indonesia: Publisher IOP publishing Ltd. https://doi.org/10.1088/1755$\underline{1315 / 404 / 1 / 012015}$

Huda, N., Fatma, Y., Fazillah, A., Adzitey, F. 2012. Chemical composition, colour and characteristics of commercial serundeng (shredded meat) in Malaysia. Pakistan Journal of Nutrition, vol. 11, no. 1, p. 1-4. http://doi.org/10.3923/pjn.2012.1.4

Kannaiyan, S. K., Bagthasingh, C., Vetri, V., Aran, S. S., Venkatachalam, K. 2019. Nutritional, textural and quality attributes of white and dark muscles of little tuna (Euthynnus affinis). Indian Journal of Geo Marine Sciences, vol. 48, no. 2, p. 205-211.

Kasmiati, Ekantari, N., Asnani, Saudi, Husni, A. 2020. Mutu dan tingkat penerimaan konsumen abon ikan layang (Decapterus sp.) (Quality and consumers acceptence of shredded macarelscad fish (Decapterus sp.). Jurnal Pengolahan Hasil Perikanan Indonesia, vol. 23, no. 3, p. 470478.

Indonesian).

https://doi.org/10.17844/jphpi.v23i3.32700

Komal, Kaur, P. 2019. Development and nutritional evaluation of banana blossom incorporated sev. International Journal of Basic and Applied Research, vol. 9, no. 8, p. 2834.

Lee, Y. C., Kung, H .F., Wu, C. H., Hsu, H. M., Chen, H. C., Huang, T. C., Tsai. Y. H. 2016. Determination of histamine in milkfish stick implicated in food-borne poisoning. Journal of Food and Drug Analysis, vol. 24, p. 6371. https://doi.org/10.1016/j.jfda.2015.06.009

Liyanage, R., Gunasegaram, S., Visvanathan, R., Jayathilake, C., Weththasinghe, P., Jayawardana, B. C., Vidanarachchi, J. K. 2016. Banana blossom (Musa acuminate Colla) incorporated experimental diets modulate serum cholesterol and serum glucose level in wistar rats fed with cholesterol. Cholesterol, p. 1-6. https://doi.org/10.1155/2016/9747412.

Lukáčová, A., Golian, j., Massanyi, P., Formicki, G. 2014. Lead concentration in meat an meat products of different origin. Potravinarstvo Slovak Journal of Food Sciences, vol. 8, no. 1, p. 43-47. https://doi.org/10.5219/334

Ministry of Marine and Fisheries Affairs. 2021. Production of fish in Indonesia, Available at: https://statistik.kkp.go.id/home.php?m=total\&i=2\#panelfooter.

Muscarella, M., Iammarino, M., Centonze, D., Palermo, C. 2005. Measurement of histamine in seafood by HPLC, CE, and ELISA: Comparison of three techniques. Veterinary
Research Communications, vol. 29, p. 343-346. https://doi.org/10.1007/s11259-005-0077-2

Nollet, L. M. L., Fidel, T. 2015. Handbook of Food Analysis. $3^{\text {rd }}$ ed. BOCA RATON, FLORIDA, USA: CRC Press, 1568 p. ISBN-9781466556546.

Novidiyanto, N., Enardi, O. P., Devriany, A.,Pratiwi, A. P.,Airuni, M. 2020. Acceptability and antioxidant activity level of shredded banana flower-chicken meat. AmertaNutrition, vol. 4, no. 4, p. 299-306. http://dx.doi.org/10.20473/amnt.v4i4.2020.299-306

Peivasteh-Roudsari, L., Rahmani, A., Shariatifar, N., TajdarOranj, B., Mazaheri, M., Sadighara, P., Khaneghah, A. M. 2020. Occurrence of histamine in canned fish samples (tuna, sardine, kilka, and mackerel) from markets in Tehran. Journal of Food Protection, vol. 83, p. 136-141. https://10.4315/0362028X.JFP-19-288

Poonsri, T., Jafarzadeh, S., Ariffin, F., Ismail, N., Barati, Z., Latif, S., Muller, J. 2019. Improving the physicochemical and antioxidant properties of fish floss incorporated with waste cassava leaves. Journal of Chemical Health Risks, vol. 9, no. 1, p. 27-34. https://doi.org/10.22034/jchr.2019.584338.1013

Puspita, M. D., Kartikaningsih, H. and Dayuti, S. 2019. The effect of banana blossom (Musa paradisiaca) on physicochemical and organoleptic characteristics of Indian scad (Decapterusrusselli) abon (Pengaruh substitusi jantung pisang (Musa paradisiaca) terhadap karakteristik fisika, kimia dan organoleptik abon ikan layang benggol (Decapterus ruselli). Thesis. Universitas Brawijaya, Malang. (in Indonesian).

Romadhon, R., Amalia, U., Anggo, A. D. 2019. Quality improvement of catfish floss (Clariasgariepinus) through oil reduction technology with spinner and press tools. OMNIAKUATIKA Journal of Fisheries and Marine Research, vol. 15, no. $2, \quad$ p. $36-42$. https://doi.org/10.20884/1.oa.2019.15.2.629

Sajib, M. A. M., Hoque, M. M., Yeasmin, S., Khatun, M. H. 2014. Minerals and heavy metals concentration in selected tropical fruits of Bangladesh. International Food Research Journal, vol. 21, p. 1731-1736.

Sęczyk, L., Świeca, M., Gawlik-Dziki, U. 2016. Effect of carob (Ceratonia siliqua L.) flour on the antioxidant potential, nutritional quality, and sensory characteristics of fortified durum wheat pasta, Food Chemistry, vol. 194, p. 637-642. https://doi.org/10.1016/j.foodchem.2015.08.086

Sharma, V., Shukla, K. V., Golani, P. 2019. Traditional and medicinal effect of banana blossom. International Journal of Scientific Development and Research, vol. 4, p. 377-381.

Sheng, Z. W., Ma1, W. H., Jin, Z. Q., Bi, Y., Sun, Z. G., Dou, H. T., Gao, J. H., Li, J. Y., Han, L. N. 2010. Investigation of dietary fiber, protein, vitamin $\mathrm{E}$ and other nutritional compounds of banana flower of two cultivars grown in China. African Journal of Biotechnology, vol. 9, no. 25 , p. $3888-3895$.

SNI 01-3707, 1995. The quality standard of fish abon (fish floss) (Standar mutu abon ikan). (In Indonesian)

SNI 7988, 2009. Maximum permissible limits of microbial contamination in food products (Batas maksimum cemaran mikroba dalam pangan). (In Indonesian)

Somsub, W.,Kongkachuichai, R.,Sungpuag, P.,Charoensiri, R. 2008. Effects of three conventional cooking methods on vitamin C, tannin, myo-inositol phosphates contents in selected Thai vegetables. Journal of Food Composition and Analysis, vol. 21, no. 2, p. 187-197. https://doi.org/10.1016/j.jfca.2007.08.002

Suprayitno, E., Adi, S. S.,Sulistiyati, T. D. 2016. Diversification of mackerel tuna (Euthynnus affinis) products 
as processed fishcake, nugget, cracker, meatball, and meat floss products at the TPI Tempursari beach tourism site, Lumajang. IOSR Journal of Humanities and Social Science, vol. 21, no. 11, p. 14-17.

Suryani, N.,Abdurrachim, R.,Alindah, N. 2016. Analysis of carbohydrate, fiber and glycemic index of processed rice siamunus as an alternative snack for diabetes mellitus (Analisis kandungan karbohidrat, serat dan indeks glikemik pada hasil olahan beras siamunus sebagai alternatif makanan selingan penderita diabetes mellitus). Jurnal Kesehatan Indonesia, vol. 7, no. 1, p. 1-9. (in Indonesian).

Timoracká, M., Vollmannová, A., Ismael, D. S. 2017. The content of polyphenols and chosen heavy metals in faba bean (Faba vulgaris Moench) relating to different doses of zinc application. Potravinarstvo Slovak Journal of Food Sciences, vol. 11, no. 1, p. 272-278. https://doi.org/10.5219/638

Wahab, N. B. A., Ismail, S. N., Abidin, M. H. S. Z. 2020. Physicochemical and sensory characteristics of banana blossom nuggets. International Journal of Research and Innovation Management, vol. 6, p. 56-65.

Wazir, H., Chay, S. Y.,Zarei, M.,Hussin, F. S., Mustapha, N. A.,Ibadullah, W. Z. W., Saari, N. 2019. Effects of storage time and temperature on lipid oxidation and protein cooxidation of low-moisture shredded meat products. $\begin{array}{llll}\text { Antioxidants, } & \text { vol. } & 8, & \end{array}$ https://doi.org/10.3390/antiox8100486.

Wijaya, I., Surti, T., Anggo, A. D., Santoso, E. 2016. Effect different packaging on proximate and lysine content of milkfish [Chanoschanos (Forsskål, 1775)] floss during storage. Aquatic Procedia, vol. 7, p. 118-124. https://doi.org/10.1016/j.aqpro.2016.07.016

Witczak, M., Jaworska, G., Witczak, T. 2020. Influence of inulin and oligofructose on the sensoryproperties and antioxidant activity of apple jelly. Potravinarstvo Slovak Journal of Food Sciences, vol. 14, no. 1, p. 774-780. https://doi.org/10.5219/1332

\section{Acknowledgments:}

The authors are thankful for the financial support provided by the Universitas Brawijaya, Indonesia through the Research Grant for Professor and Doctor 2020, grant number 35, 2020. Also, we are grateful for the payment of article processing charge (APC) of the Universiti Malaysia Sabah, for joining publication.

\section{Conflict of Interest:}

The authors declare no conflict of interest.
This article does not contain any studies that would require an ethical statement.

\section{Contact Address:}

Hartati Kartikaningsih, Department of Fishery Product Technology and Bioseafood Research Group, Faculty of Fisheries and Marine Science, Universitas Brawijaya, Jl. Veteran 65145, Malang, Indonesia, Tel.: +62341551611, E-mail: hartatikartikan@ub.ac.id

ORCID: https://orcid.org/0000-0002-5124-1512

Yahya, Department of Fishery Product Technology and Bioseafood Research Group, Faculty of Fisheries and Marine Science, Universitas Brawijaya, Jl. Veteran 65145, Malang, Indonesia, Tel.: +62341551611,

E-mail: yahya.mp@ub.ac.id

ORCID: -

Yuniar Tri Hartita, Department of Fishery Product Technology, Faculty of Fisheries and Marine Science, Universitas Brawijaya, Jl. Veteran 65145, Malang, Indonesia, Tel.: +62341551611,

E-mail: trihartitauyuniar@gmail.com

ORCID: https://orcid.org/0000-0002-6349-6774

Abdul Aziz Jaziri, Department of Fishery Product Technology and Bioseafood Research Group, Faculty of Fisheries and Marine Science, Universitas Brawijaya, Jl. Veteran 65145, Malang, Indonesia, Tel.: +62341551611,

E-mail: azizjaziri@ub.ac.id

ORCID: https://orcid.org/0000-0001-7121-4055

Wahidu Zzaman, Department of Food Engineering and Tea Technology, Shahjalal University of Science and Technology, Sylhet-3114, Bangladesh,

E-mail: wahidanft@yahoo.com / wahid-ttc@sust.edu

ORCID: https://orcid.org/0000-0003-1513-7301

Rovina Kobun, Faculty of Food and Nutrition, Universiti Malaysia Sabah, Jalan UMS, 88400 Kota Kinabalu, Sabah, Malaysia, Tel.: +6088320000,

E-mail: rovinaruby@ums.edu.my

ORCID:https://orcid.org/0000-0002-4985-9145

*Nurul Huda, Faculty of Food and Nutrition, Universiti Malaysia Sabah, Jalan UMS, 88400 Kota Kinabalu, Sabah, Malaysia, Tel.: +6088320000; Department of Food Science and Technology, Faculty of Agriculture, Universitas Sebelas Maret, J1. Ir. Sutami, Surakarta, 57126, Central Java, Indonesia,

E-mail: drnurulhuda@ums.edu.my

ORCID: https://orcid.org/0000-0001-9867-6401

Corresponding author: * 